The Role of Information for Energy Efficiency in the Residential Sector

\author{
Ana Ramos \\ Alberto Gago \\ Xavier Labandeira \\ Pedro Linares
}




\title{
The Role of Information for Energy Efficiency in the Residential Sector
}

\author{
Ramos, A. ${ }^{a^{*}}$, Gago, A. ${ }^{a}$, Labandeira, X..$^{a, b}$, Linares, P.c \\ a Rede, Universidade de Vigo, Facultade de CC.EE., Campus As Lagoas s/n, 36310 Vigo, Spain. \\ b FSR-Climate (European University Institute), Via delle Fontanelle 19, 50014 San Domenico di Fiesole, Florence, Italy. \\ C Instituto de Investigación Tecnológica, Universidad Pontificia Comillas, Alberto Aguilera 23, 28015 Madrid, Spain.
}

\begin{abstract}
In spite of the large potential and existing efforts to foster energy efficiency in the residential sector, much remains to be achieved. This may be partially due to the many barriers and market failures faced by energy efficiency, which are even greater in the residential sector. In particular, informational failures seem to be pervasive and relevant in this area. Addressing these issues requires specific policy instruments and strategies. This paper reviews the empirical evidence on the effectiveness of such instruments, focusing on energy certificates, feedback programs, and energy audits. Results show that energy certificates and feedback programs can be effective, but only if they are carefully designed. Yet energy audits seem to have little effect on efficiency. In addition, the paper points out the large potential for new instruments as well as combinations of existing ones.
\end{abstract}

Keywords: Energy efficiency, information, behavior.

JEL Classification: Q40, Q48, Q58.

\footnotetext{
* Corresponding author

E-mail addresses: anaramos@uvigo.es (A. Ramos), agago@uvigo.es (A. Gago), xavier@uvigo.es (X. Labandeira), pedro.linares@upcomillas.es (P. Linares).
} 


\section{Energy efficiency in the residential sector}

Many international institutions (IEA, 2013; European Commission, 2011; OECD, 2003) suggest that energy efficiency is the best tool to keep energy demand under control and transition towards a low-carbon future. This consensus extends to the key role of the residential sector in this strategy, given that it presents the highest cost-efficient potential for mitigation?.

Therefore, many governments have made it a priority to improve energy efficiency levels in buildings and they are seeking to promote this through several different policies. These policies, mostly directed towards the residential sector, have generally consisted in building codes and standards, and also price instruments such as taxes and subsidies (Markandya et al., 2015). However, in spite of the significant efforts and resources devoted to making these policies, the results have not been as expected. In Europe, for instance, a comparatively intense use of EU and national policies to promote energy efficiency has coexisted with a growing energy demand in the residential sector, with an apparently large unexploited energy saving potential (European Parliament, 2014).

Indeed, a close look at the situation highlights the existence of several barriers associated to energy efficiency measures in buildings as another proof of the 'energy efficiency paradox' (Jaffe and Stavins, 1994), the divergence between optimal and real energy efficiency levels. Optimal energy efficiency levels are rarely met in a sector characterized by dualities in stock (existing vs. new buildings), in the use of buildings (commercial vs. residential) and in the preferences of the agents that participate (owners vs. renters), and this is due to many barriers. The consequence is that energy efficiency does not reach levels corresponding to the many 'win-win' opportunities existing in this market, or even to the willingness to pay (WTP) expressed by consumers².

Until recently, the standard framework for dealing with the energy efficiency gap was based on the traditional analysis of market failures. This resulted in public interventions through economic (price or quantity) instruments and standards. For example, energy prices usually do not internalize environmental (or other) externalities derived from the use of energy and this, in turn,

\footnotetext{
${ }^{1}$ Currently, buildings consume one third of global final energy, and the same share of carbon emissions is directly or indirectly related to this sector (IEA, 2013). In the UE the construction sector consumes $40 \%$ of primary energy and is responsible for $36 \%$ of greenhouse gas emissions (European Commission, 2013). This figure will only grow because of the increase in the building stock and energy intensity in fast-growing countries such as China or India.

2 Over the last decade, the empirical literature has tried to estimate this WTP for insulation measures or efficient cooling or heating systems. Most of these studies have concluded that the WTP was positive in these cases. Banfi et al. (2008) obtained positive results for a hypothetical change of insulation and ventilation systems for apartment renters and house owners in Switzerland. However, the analysis of the determinants was limited because they could not include socioeconomic variables. Also for Switzerland, Alberini et al. (2013) found a positive WTP for owners of semi-detached and detached houses, although this was only for those owners who expected increases in energy prices or those that were convinced of the relevance of house rehabilitation programs within climate policies were willing to alter their status quo. In the econometric analysis, socioeconomic variables were not significant. Similar results have been obtained for Germany (Achtnicht, 2011) or South Korea (Kwak et al., 2010) and Hong Kong (Chau et al., 2010).
} 
determines excessive pollutant levels or a higher than optimal energy use (Gillingham et al., 2009). If the price of energy does not correspond to the real marginal cost, the adoption of energy efficiency measures will be disincentivized. This market failure demands public intervention to take prices to their right level, including social costs.

Another typical problem is the lack of access to, or the excessive cost of, capital either due to uncertainty issues (Blumstein et al., 2004), energy poverty, or other problems. There have been some studies on these issues, but results are not very clear as of yet ${ }^{3}$.

But even if government intervention takes place to tackle market failure, the use of conventional regulatory instruments has shown many limitations. For example, Iwaro and Mwasha (2010) collect information about 60 countries in Africa, Latin America and Middle East, and argue that, in spite of the recent growing use of energy standards in these countries, most of these standards are far from the ones set in developed countries. But even in advanced economies the effects of building codes on energy consumption seem to be reduced: Levinson (2014), for instance, finds no effects in California, whereas Aroonruengawat et al. (2012) and Jacobsen and Kotchen (2013) find only limited reductions in respectively the US and Florida. The use of price instruments, such as energy taxes, has also been limited by the low elasticity of energy demand, as showed by Gillingham et al. (2009) or Ryan et al. (2011) in this area. Finally, although subsidies could be very effective given that investment cost is one of the most relevant factors for consumers (Mourato et al., 2004; Nair et al., 2010a), making unrestricted use of them typically results in inefficiencies due to high fiscal cost and the free-riding effect ${ }^{4}$.

The evidence of the reduced levels of energy efficiency attained through conventional policies raises the question of whether the traditional approach, in which consumers have perfect information and make rational decisions, corresponds to real energy efficiency markets in buildings ${ }^{5}$ (Stern et al., 1987). Probably the preceding analysis is too limited and requires relaxing these assumptions and incorporating other elements such as imperfect information or behavioral failures (Allcott and Mullainathan, 2010; Shogren and Taylor, 2008). The key role assigned to behavioral failures has opened the way to new policies (Tietenberg, 2009) as well as to the sizeable empirical research presented in this paper.

This new approach also means letting go of the traditional classification of instruments that distinguished market failures from other barriers (Jaffe et al., 2004; Jaffe and Stavins 1994) and

\footnotetext{
3 The work of Scott (1997) for Ireland confirms the positive impact of household income on the probability of adopting energy efficiency measures. However, Brechling and Smith (1994) found a reduced effect of this variable in England.

${ }^{4}$ Banfi et al. (2008) and Grösche and Vance (2009), for example, observed that for a very high share of households in Switzerland and Germany, the willingness to pay for certain energy efficiency measures exceeded the investment cost.

${ }^{5}$ As already pointed out for many sectors by Kahneman (2011), Mullainathan and Thaler (2000) or Simon (1955).
} 
moving on to a new typology (Gillingham et al., 2009; Stavins et al., 2013), summarized in Table 1.

Table 1. Reasons for the Energy Efficiency Paradox

\begin{tabular}{l|c|c|c}
\hline & Market failure & $\begin{array}{c}\text { Behavioral } \\
\text { failure }\end{array}$ & Other barriers \\
\hline Low energy prices & $\mathrm{X}$ & & $\mathrm{X}$ \\
\hline Hidden and transaction costs & & $\mathrm{X}$ & $\mathrm{X}$ \\
\hline Uncertainty and irreversibility & & $\mathrm{X}$ & \\
\hline Information failures & $\mathrm{X}$ & $\mathrm{X}$ & \\
\hline Decision-making heuristics and biases & & & \\
\hline Slowness of technological diffusion & $\mathrm{X}$ & & \\
\hline Principal-agent problem & $\mathrm{X}$ & & $\mathrm{X}$ \\
\hline Capital markets imperfections & & & $\mathrm{X}$ \\
\hline Heterogeneity of consumers & & & $\mathrm{X}$ \\
\hline Divergence with social discount rates & & & \\
\hline
\end{tabular}

Source: The authors, adapted from Linares and Labandeira (2010).

The most recent literature inquires whether there is space to introduce new energy efficiency policies that exploit these informational and behavioral failures. In particular, scholars have focused on information programs and behavioral interventions ${ }^{6}$ as ways to close the energy efficiency gap. Indeed, information instruments have become increasingly popular as regulators may use them to mitigate the negative effects of imperfect information or behavioral failures. Of course, the amount of information provided depends on the type of instrument chosen: i) Certificates or labels that show the energy efficiency of a product; ii) Feedback to customers, which can be channeled through smart meters that show real-time energy consumption and bills with comparative information about similar or representative households; and iii) Energy audits that inform about specific measures households may adopt to reduce consumption.

It then makes sense to talk about two generations of instruments for energy efficiency in buildings. The left side of Figure 1 shows first-generation, traditional instruments, while the right side shows second-generation instruments. The latter are considered very powerful in terms of achieving energy savings and have been widely adopted in many places given their low implementation cost.

6 These interventions try to induce more efficient behaviors through "nudges" such as feedback, commitments, goal setting, social comparisons, normative messages, or manipulation of default options (Brown et al., 2013; Croson and Treich, 2014; Ehrhardt-Martinez et al., 2010). 
Figure 1. Two Generations of Energy Efficiency Policy Instruments for Buildings

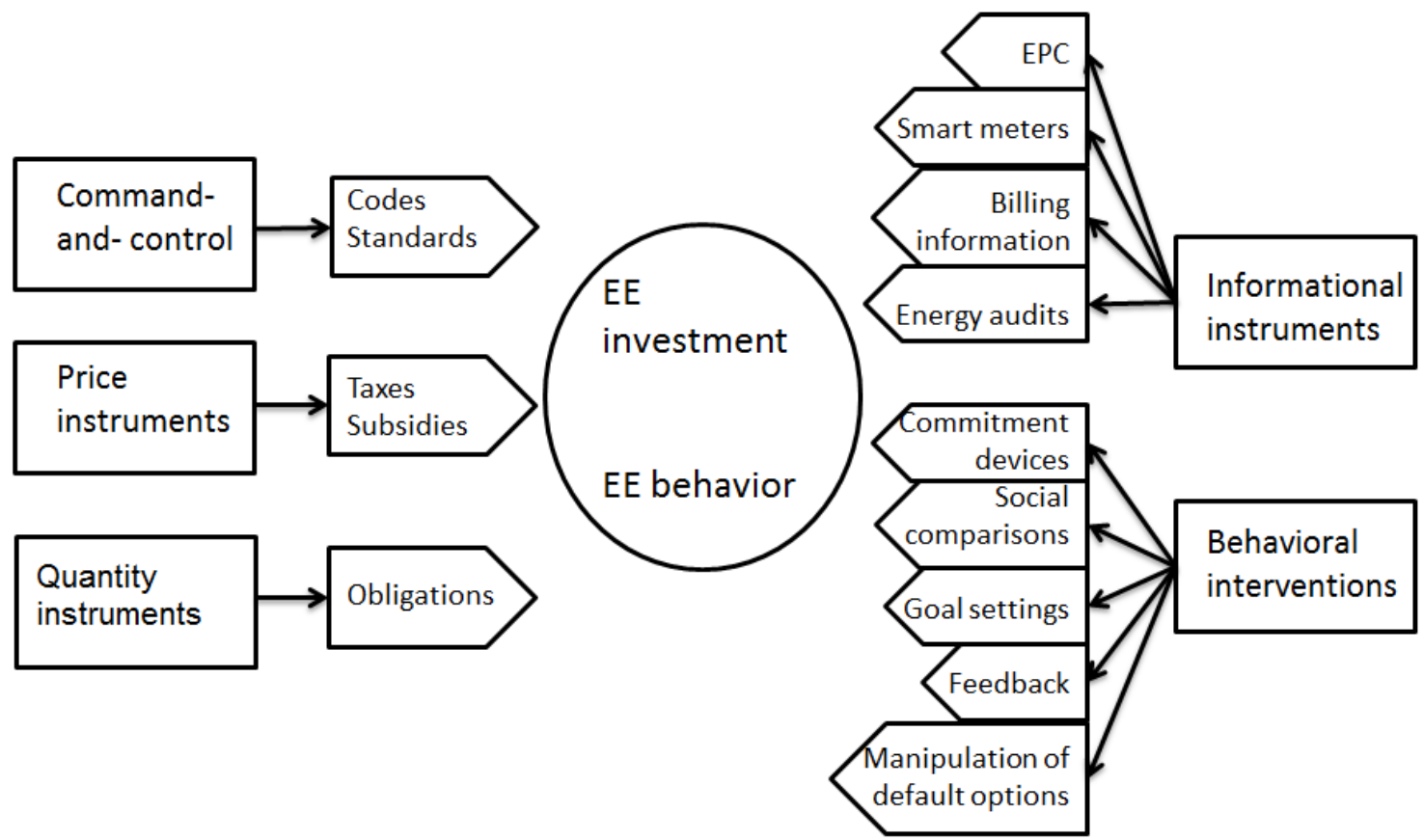

Source: The authors.

Until recently, most empirical evidence focused on the assessment of cost-efficiency of conventional or first-generation policies (Gillingham et al., 2006; Ürge-Vorsatz and Novikova, 2008) with ex-ante models that estimated and compared the expected results of each instrument. Recently, though, there have been many advances in the empirical analysis of energy efficiency in buildings by using ex-post data and also by progressing in the study of consumer behavior. The widespread application of energy efficiency policies has provided large databases that allow estimating the real impacts of these policies, and the determinants of the agents' decisions, thus improving our understanding of household behavior. In addition, experimental methodologies with rigorous design and the use of large-scale random samples are extensively being employed to study novel aspects of energy efficiency in buildings.

This paper provides an update on the knowledge of the performance of energy efficiency policies, with a particular emphasis on 'second-generation' informational instruments. It contributes to the state of the art in two ways. First, it presents a comprehensive picture that permits us to relate conventional and informational instruments, with the final goal of defining integrated policy packages. Second, to the best of our knowledge, it is the first attempt at compiling all the 
empirical evidence about informational instruments applied to energy efficiency in buildings ${ }^{7}$. Given that the development of these second-generation instruments has run parallel to that of other markets, such as vehicles or appliances, we will also refer to them in order to provide a more integrated view of the new role information will have to play in sectors presenting substantial barriers for conventional instruments.

We begin by describing the way in which informational and behavioral problems contribute to the energy efficiency gap (Section 2), and then move on to reviewing the empirical evidence on the performance of instruments designed to address these problems: energy labels and certificates, smart meters, bills with comparative information, and energy audits (Section 3). The review shows that the impact of informational instruments on energy efficiency in buildings is positive, although variable. The new approaches identified also show the potential for clearer results in the near future, highlight the difficulties of using only conventional instruments, and pave the way for the design of new broad, integrated policy packages for energy efficiency in buildings in which informational instruments play a big part. We finish with some conclusions and directions for future research.

\section{The role of information and behavior in the energy efficiency paradox}

As mentioned earlier, informational and behavioral failures may play a very significant role in explaining the energy efficiency paradox. This section reviews the major aspects of this matter.

\subsection{Asymmetric and incomplete information}

The fact that consumers do not observe the amount of electricity consumed by a washing machine during a washing cycle or the energy required by a house to maintain the right temperature makes energy efficiency an intangible characteristic of energy goods. Therefore the nature of energy efficiency itself creates several problems related to information, which is frequently incomplete, generally asymmetric, and almost always costly to obtain. As a result, consumers value this unobservable characteristic less and tend to not include it among their preferences when buying a new product and this, in turn, prevents them from managing their energy use in the right way.

\footnotetext{
7 This paper also includes references to energy efficiency programs in the commercial sector. However, households do not typically follow the same rationale as firms; this gives rise to more barriers and requires a larger and more complex public intervention.
} 
Determining the energy efficiency of a product is a complex task, generally restricted to experts, which also creates a situation of asymmetric information. Some agents have all the information, whereas for others accessing this information is difficult and costly. On the other hand, consumers cannot assess how reliable this information is and this makes them uncertain about adopting energy efficiency measures. This uncertainty is further compounded by the variability of future energy prices and changing regulatory environments, and all of this together makes it harder to estimate the economic return of investments. Given that these investments are irreversible, uncertainty clearly deters them.

Hidden or transaction costs may also be included among the information problems. These costs are frequently not incorporated in cost-benefit analysis, thus leading to an overestimation of net benefits. Many authors such as Allcott and Greenstone (2012), Brechling and Smith (1994), Clinch and Healy (2000), Jaffe et al. (2004) or Jaffe and Stavins (1994) suggest that including these costs reduces the energy efficiency gap.

\subsection{Principal-agent and split incentives}

These problems are typically related to asymmetric information. They arise when the incentives for the different agents involved in a transaction are not aligned and lead to an inefficient allocation of resources.

The characteristic duality of the building sector for rental buildings (owners and tenants) particularly affects energy efficiency decisions. If the house owner does not live there, or if the tenant does not pay directly utility costs, then energy use may be higher given the lack of the right price signal (Maruejols and Young, 2011). The benefits of energy savings do not accrue to the owner who, nonetheless, must pay for the new investments. As a result, investments in energy efficiency are lower than optimal.

Over the last decade, a great effort has been made to identify and quantify these distortions. In the absence of specific databases, some researchers have used investment in energy efficiency and the use of energy for heating or cooling (from household surveys) and have applied binary choice models to estimate the effect of ownership. This is the case, for example, of Brechling and Smith (1994), who identified ownership as the single socioeconomic factor that, together with the rest of structural characteristics of the dwelling, has a significant effect on the probability of investing in energy efficiency. Similar results were obtained for Ireland by Scott (1997). Also, Schleich and Gruber (2008), using a sample of 19 sub-sectors in the commercial and residential sectors in Germany, identified principal-agent and imperfect information problems as the most important barriers to achieving optimal levels of energy efficiency. 
The availability of specific surveys for energy use has permitted a wider range of approaches and applied empirical techniques. With data from the Residential Energy Consumption Survey and the American Housing Survey, Levinson and Niemann (2004) analyzed the incidence of the principalagent problem on the temperature set by households in winter. Using probit and OLS regression models, they revealed a negative effect when contracts included heating expenses in the rental cost. These results were confirmed for Canada, using data from the Household Energy Use survey, by Maruejols and Young (2011). They also showed that multi-family buildings, in which households do not directly pay for heating, are more likely to set higher temperatures.

More recently, Gillingham et al. (2012), using a large sample of households from the California Statewide Residential Appliance Saturation Study, show that households occupied by owners have a $20 \%$ higher probability of featuring insulation in roofs and attics while households whose tenants directly pay for energy have a $16 \%$ higher probability of changing the temperature set during the night. With a linear probability model, and data from the US, Davis (2012) also confirmed the relevance of the principal-agent problem for buying efficient appliances and lighting systems because tenants who do not directly pay for electricity have a lower probability of buying this type of equipment.

Finally, the IEA (2007) has tried to approximately quantify the amount of energy affected by this problem, using as case studies the residential, commercial and final energy use sectors in Japan, US, the Netherlands, Norway and Australia. If we take a look at the extremes we see that this problem could affect $40 \%$ of the energy consumed in office buildings and $41 \%$ of the energy used for heating in the residential sector in the Netherlands, whereas in Norway $15 \%$ of the energy consumed in the commercial sector could be saved by aligning incentives.

\subsection{Behavioral failures}

Over the last years, the hypothesis formulated by behavioral economics claiming that consumers systematically deviate from the perfect rationality ${ }^{8}$ assumed by neoclassical economics has become more and more relevant in assessing public policies (DellaVigna, 2009; Mullainathan and Thaler, 2000). Following Shogren and Taylor (2008), we use the term 'behavioral failures' for all those situations in which the consumer does not behave according to rational choice theory. There are many behavioral failures and also many typologies, some of which depend on the theory considered to explain these failures, the major ones being Prospect theory (Kahneman

\footnotetext{
${ }^{8}$ Readers interested in this topic may refer to the recent books of Kahneman (2011) or Thaler and Sunstein (2008), which, although directed to a general public, compile most of the relevant academic literature and present it in a clear way.
} 
and Tversky, 1979); Bounded rationality (Simon, 1955); and Regret theory (Loomes and Sugden, 1982). Box 2 summarizes the most relevant failures described in the literature.

Table 2. A summary of the major behavioral failures

\begin{tabular}{|c|c|c|}
\hline Type & Behavioral failure & Explanation \\
\hline \multirow{12}{*}{$\begin{array}{l}\text { Deviations from } \\
\text { rational theory of } \\
\text { choice }\end{array}$} & Framing & The way a problem is framed impacts the final decision \\
\hline & Preference reversal & $\begin{array}{l}\text { There may be differences between values and choices } \\
\text { which result in reversal of preferences }\end{array}$ \\
\hline & Preference intransitivity & $\begin{array}{l}\text { Preferences may not be consistent, and may form on } \\
\text { the spot, resulting in intransitive cycles }\end{array}$ \\
\hline & $\begin{array}{l}\text { Independence of irrelevant } \\
\text { alternatives }\end{array}$ & $\begin{array}{l}\text { Alternatives that should be irrelevant become very } \\
\text { important for the final decision }\end{array}$ \\
\hline & $\begin{array}{l}\text { Endowment or "status-quo" } \\
\text { effect }\end{array}$ & $\begin{array}{l}\text { Tendency to value more what we have, or the starting } \\
\text { situation }\end{array}$ \\
\hline & Gambling and insurance & $\begin{array}{l}\text { Partly based on the latter (the starting or reference } \\
\text { point), people will have different attitudes towards risk } \\
\text { depending on its magnitude and starting point }\end{array}$ \\
\hline & Sunk cost fallacy & $\begin{array}{l}\text { People consider sunk costs in their decisions, although } \\
\text { they should not, based sometimes on self-discipline or } \\
\text { stability of decisions }\end{array}$ \\
\hline & Mental accounting & $\begin{array}{l}\text { People allocate different expenses to different } \\
\text { categories, as a way to deal with complexity in } \\
\text { budgeting }\end{array}$ \\
\hline & Dynamic inconsistency & Preferences change when decisions come closer. \\
\hline & Limited attention & $\begin{array}{l}\text { People are not able to use all the available information } \\
\text { due to time or effort constraints }\end{array}$ \\
\hline & The paradox of choice & $\begin{array}{l}\text { More options result in less utility (maybe because of } \\
\text { larger regret) }\end{array}$ \\
\hline & Emotions & $\begin{array}{l}\text { Emotions, altruism, social norms, may have a } \\
\text { significant effect on decisions }\end{array}$ \\
\hline \multirow[t]{6}{*}{$\begin{array}{l}\text { Biases when } \\
\text { dealing with } \\
\text { uncertainty }\end{array}$} & $\begin{array}{l}\text { Representativeness/ Conjunction } \\
\text { fallacy }\end{array}$ & $\begin{array}{l}\text { People look for internally-consistent stories, even if } \\
\text { they go against probabilities. It is also used when } \\
\text { people extrapolate small samples to large ones. }\end{array}$ \\
\hline & Availability & $\begin{array}{l}\text { People make judgments about the probability of events } \\
\text { by how easy it is to think of examples }\end{array}$ \\
\hline & Anchoring & Estimations are biased by the number initially provided \\
\hline & Gambler's fallacy & $\begin{array}{l}\text { Based on misconceptions of randomness, people are } \\
\text { not able to estimate the likelihood of random } \\
\text { sequences }\end{array}$ \\
\hline & Selection bias & $\begin{array}{l}\text { When the sample selected is not random, results will } \\
\text { be biased }\end{array}$ \\
\hline & Aversion to uncertainty & $\begin{array}{l}\text { People assign lower utility to results for which } \\
\text { probabilities are not known }\end{array}$ \\
\hline
\end{tabular}

Source: The authors. 
Allcott and Mullainathan (2010), Dyner and Franco (2004), Gillingham et al. (2009), Shogren and Taylor (2008) or Tietenberg (2009) have already pointed out the relevant role that this approach may play in understanding the energy efficiency gap. Bounded rationality, for example, may prevent consumers from correctly estimating the future energy performance of a house, or it may lead them to consider only the more salient or familiar features when choosing between the many attributes of a house, a car or a fridge. Risk aversion or reference dependence ('status quo' bias) may also limit the potential to actually achieve the estimated savings. All of this may result in lower than expected energy efficiency levels.

One reason for these behavioral failures is the lack of knowledge about energy costs even though they represent a significant part of household income. Brounen et al. (2013) illustrate this possibility with a survey on 1,721 households in the Netherlands, in which around $50 \%$ of the respondents did not know their energy expenses (the average energy bill is 222 Euro, $8 \%$ of income). Nair et al. (2010b) show that this issue also has negative effects on energy efficiency in Swedish households given that families believing their energy expenses are high are more likely to invest in energy efficiency.

Although DellaVigna (2009) and Gillingham and Palmer (2013) have reviewed the empirical evidence of this type of behavioral failures in several fields, its extension to energy efficiency in buildings is limited as of yet. It is difficult to robustly measure the behavior of consumers in a market as complex as energy efficiency in buildings. Considerable analysis is still required to settle very relevant questions, such as how these failures affect energy efficiency, how behavioral and market failures relate, or whether these failures can be corrected through learning or repetition (Shogren and Taylor, 2008)9.

\section{The evidence on information-based energy efficiency policies}

Acknowledging the relevance of the informational and behavioral failures in the energy efficiency gap has promoted the design of policies that try to give better information to consumers and enable them to avoid non-rational behaviors and adopt the most efficient decisions. For example, the European Directive for Energy Efficiency (2012/27/EU) has focused on demand management programs for households, as an alternative to price instruments. Information-based instruments, such as energy certificates, energy audits, or information of energy use, are not only less costly to implement but can also be very effective in achieving energy efficiency (Allcott and Mullainathan,

\footnotetext{
9 The heterogeneity of households should also be taken into account. The behavior of consumers may depend on cultural or ideological factors. Some studies, for example, have found empirical evidence on the importance of concern for the environment in energy use and energy efficiency of residential consumers, as in Costa and Kahn (2010a), Di Maria and Lazarova (2008), Kahn and Vaughn (2009), Kotchen and Moore (2007), Lange et al. (2014) and Ramos et al. (2015). Another source of heterogeneity is the different use of home appliances (Houde, 2014a).
} 
2010; Ayres et al., 2012). In this section we review empirical evidence on the performance of information-based instruments.

\subsection{Energy certificates and labels}

Energy certificates or label programs have quickly expanded over the last years. These certificates or labels use different colors or symbols to show different energy efficiency levels. In general, these levels are determined according to the structural characteristics of the product and their importance in its energy performance. In some countries, such as the US, energy certificates are voluntary and only used for very efficient products ${ }^{10}$. In the European Union, energy certificates are mandatory for appliances, vehicles and buildings, and all products are classified based on their energy efficiency level (in a scale from $A$, most efficient, to $G$, least efficient) ${ }^{11}$.

In the case of buildings, energy certificates have proliferated in developed countries over the last few years. They vary depending on their public or private character; on the typology of the buildings targeted (residential or commercial); and on their mandatory or voluntary nature. At the same time, there has been a strong development of the empirical research assessing their impact on consumers' decisions and the price of buildings. Some studies have also looked at the effectiveness of the institutional and design aspects of these instruments. Mlecnik et al. (2010), for example, surveyed experts in 25 countries to identify the barriers and elements capable of improving the diffusion of certificates: increasing their relative advantages and their visibility and transparency for consumers; or reducing complexity and facilitating the transfer of knowledge. Bull (2012) highlighted the importance of the frame in which information is offered. Through a choice experiment, he showed the importance of informing about the monetary value of the energy savings, or the economic losses incurred, instead of the potential benefits. Banerjee and Solomon (2003) used existing studies and reports to compare the effects on consumers and manufacturers of five (private and public) energy labeling programs for appliances and electricity in the US. Their results showed that public systems were more successful and stressed the importance of the government in providing credibility and stability to these programs. The IEA (2010) also confirmed that the effect of a mandatory system is higher because more buildings are identified, but it warned that public costs increase with such a system.

The market has not yet been able to generate enough data to estimate the effect of introducing certificates on energy demand, whether at the aggregate or disaggregate level. However, it is possible to estimate the direct effect of energy certificates on the decisions of the agents. The

\footnotetext{
10 In the US there are two voluntary systems for energy certificates: the Energy Star program for appliances, managed by the Environmental Protection Agency; and the LEED program for buildings.

11 These systems are regulated by Directives 2012/27/EU, 1999/94/CE and 1992/75/CEE.
} 
value of certificates can be also obtained from the WTP of consumers, first quantified by Eichholtz et al. (2010) with the use of hedonic prices (Rosen, 1974) and subsequently followed by others. Working with real estate transaction databases, this method allows for the use of econometric models that control thermal conditions of the buildings, as well as other hedonic characteristics (vintage, location, etc.) to determine the WTP of buyers or renters.

Table 3 summarizes the major empirical evidence on WTP for certificates. A first group of studies were carried out in the commercial sector in the US, from information compiled in the CoStar database (Eichholtz et al., 2013; Eichholtz et al., 2010; Fuerst and McAllister, 2011a, 2011c; Reichardt et al., 2012; Wiley et al., 2010). All these studies estimated that energy-efficient buildings (with LEED or EnergyStar certificates) obtained higher rents or selling prices than others with the same characteristics but no certificate. Although they used smaller databases, Das et al. (2011) and Bloom et al. (2011) confirmed these results for San Francisco, Washington DC and Colorado. Interestingly the results of these studies also show a positive relation between certification and the occupation rate in commercial buildings, in addition to the fact that part of the WTP could be attributed not only to the expected energy use but also to unobservable factors such as the environmental attitude of the consumers or the reputational effect (Eichholtz et al., 2013; Muehlegger and Gallagher, 2011).

Similar studies have been carried out in other countries with varying results. Fuerst and McAllister (2011b) did not find any effect for the commercial sector in the UK, although Chegut et al. (2013) did find it for London. Kok and Jennen (2012) also found a positive effect for the commercial sector in the Netherlands, showing that inefficient commercial buildings (those with a $D$ or lower grade) were rented at a $6 \%$ discount.

As for the residential sector, results also overwhelmingly point to a positive WTP for certified homes. In Europe Brounen and Kok (2011) studied the response of Dutch households to the EU energy certificate system and found that homes with an $A, B$ or $C$ certificate achieved premiums of $3.6 \%$ in their selling price as compared to others. Högberg (2013) used the information on standard energy use included in the certificate to determine if energy use is capitalized in the selling price of homes in Sweden. Using a sample of more than 1,000 homes in Stockholm they also confirmed that there is a positive relation between energy use and selling price. Hyland et al. (2013), in turn, used a panel with data for selling and renting prices from the website of a real estate company from 2008 to 2012 in Ireland. Following the same methodology as Brounen and Kok (2011) they found that an A home was sold at 9.3\% more than a D home, and a B home was sold at $5.2 \%$ more than a $D$ home, whereas a $F$ or $G$ home had a $10.6 \%$ discount as compared to a D home. The Irish study found that the WTP was $1.8 \%$ more for an A house, and $3.9 \%$ more for a D house. Cajias and Piazolo (2013) confirmed these results for Germany between 2008 and 2010. 
Table 3. Empirical Research on the Value of Certificates or Labels for Energy products

\begin{tabular}{|c|c|c|c|c|}
\hline & \multirow[t]{2}{*}{ STUDY } & \multirow[t]{2}{*}{ SECTOR } & \multicolumn{2}{|c|}{ RESULTS: WTP } \\
\hline & & & Rent (effective) & Sales \\
\hline \multirow[t]{20}{*}{ Buildings } & Eichholtz, et al. (2010) & Commercial U.S. & $3 \%(7 \%)$ & $16 \%$ \\
\hline & Eichholtz et al. (2013) & Commercial U.S. & $3 \%(8 \%)$ & $13 \%$ \\
\hline & Wiley et al. (2010) & Commercial U.S. & $\begin{array}{l}\text { 7-9\% Energy Star } \\
15-17 \% \text { LEED }\end{array}$ & $\begin{array}{l}\text { 30\$/f2 Energy Star } \\
\text { 130\$/f2 LEED }\end{array}$ \\
\hline & Fuerst and McAllister (2011a) & Commercial U.S. & $4-5 \%$ & $25 \%$ \\
\hline & Fuerst and McAllister (2011c) & Commercial U.S. & $\begin{array}{l}3 \% \text { Energy Star } \\
5 \% \text { LEED } \\
9 \% \text { Energy Star+LEED. }\end{array}$ & $\begin{array}{l}\text { 18\% Energy Star } \\
25 \% \text { LEED } \\
28-29 \% \text { Energy Star+LEED. }\end{array}$ \\
\hline & Reichardt et al. (2012) & Commercial U.S. & $\begin{array}{l}2.5 \% \text { Energy Star } \\
2.9 \% \text { LEED. }\end{array}$ & \\
\hline & Das et al. (2011) & Commercial U.S. & Positive and dynamic & \\
\hline & Bloom et al. (2011) & Commercial U.S. & & $8.66 \$ / f 2$ \\
\hline & Kok and Jennen,(2012) & $\begin{array}{l}\text { Commercial } \\
\text { Netherlands }\end{array}$ & $-6 \%$ & \\
\hline & Fuerst and McAllister (2011b) & Commercial UK & Not significant & Not significant \\
\hline & Chegut et al. (2013) & Commercial London & $19.7 \%$ & $14.7 \%$ \\
\hline & Brounen and Kok (2011) & $\begin{array}{l}\text { Residential } \\
\text { Netherlands }\end{array}$ & & $3.6 \%$ \\
\hline & Högberg (2013) & Residential Sweden & & Positive WTP \\
\hline & Hyland et al. (2013) & Residential Ireland & $\begin{array}{l}\text { A: } 1.8 \% \\
\text { B: } 3.9 \% \\
\text { C: not significant } \\
\text { E: }-1.9 \% \\
\text { F/G: }-3.2 \%\end{array}$ & $\begin{array}{l}\text { A: } 9.3 \% \\
\text { B: } 5.2 \% \\
\text { C: } 1.7 \% \\
\text { E: not significant } \\
\text { F/G: }-10.6 \% \text {. }\end{array}$ \\
\hline & Cajias and Piazolo (2013) & Residential Germany & $\begin{array}{l}\text { Total returns: } \\
\text { B: } 2.27 \% \\
\text { C: } 2.34 \% \\
\text { D: } 2.69 \% \\
\text { E/F: not significant } \\
\text { G: reference }\end{array}$ & \\
\hline & Yoshida and Sugiura (2011) & Residential Tokyo & & Negative \\
\hline & Deng et al. (2012) & Residential Singapore & & $4 \%$ \\
\hline & Zheng et al. (2012) & Residential Beijing & Negative & Negative \\
\hline & Wall et al. (2013) & Residential U.S. & & $\begin{array}{l}\text { Positive for houses built 1996- } \\
2005 \text {. } \\
\text { Not significant for newer houses. } \\
\text { Values reach up to } 20 \%\end{array}$ \\
\hline & Kahn and Kok (2014) & Residential California & & $9 \%$ \\
\hline \multirow[t]{7}{*}{ Appliances } & Galarraga et al. (2011) & Dishwashers Spain & & $15,6 \%$ \\
\hline & Sammer and Wüstenhagen (2006) & $\begin{array}{l}\text { Washing machines } \\
\text { Switzerland }\end{array}$ & & Positive \\
\hline & Wallander (2008) & $\begin{array}{l}\text { Washing machines } \\
\text { U.S. }\end{array}$ & & Not significant \\
\hline & Shen and Saijo (2009) & $\begin{array}{l}\text { Refrigerators and air } \\
\text { conditioners Shanghai }\end{array}$ & & Positive with large variation \\
\hline & Ward et al. (2011) & Refrigerators U.S. & & Positive \\
\hline & Newell and Siikamäki (2014) & Water heaters U.S & & $\begin{array}{l}\text { Depends on the disclosed } \\
\text { information }\end{array}$ \\
\hline & Houde (2014a) & Refrigerators U.S. & & Positive for some groups \\
\hline \multirow[t]{2}{*}{ Vehicles } & Galarraga et al. (2014) & Private cars Spain & & Positive \\
\hline & Alberini et al. (2014) & $\begin{array}{l}\text { Private cars } \\
\text { Switzerland }\end{array}$ & & Positive \\
\hline
\end{tabular}

Source: The authors. 
There have also been studies for Asia, with heterogeneous results. Deng et al. (2012) used a hedonic model with two stages to control for the location effect of apartment buildings in Singapore. In their results, the value of the certificate used (Green Mark) increases the selling price of homes by $4 \%$. However, Yoshida and Sugiura (2011) found that, if the hedonic pricing model is controlled for vintage and quality of the building, then the energy certificates used in Tokyo could even have a negative effect on the price of the home, due to the higher cost of the efficient systems. Another explanation might be the potential rebound in energy consumption. For example, Newsham et al. (2009) found that, on average, LEED buildings decrease their energy consumption by $18-39 \%$. Yet they also found that $28-35 \%$ of them had increased their energy consumption. Zheng et al. (2012) studied the value of buildings that were publicized as "green", showing that this characteristic had a positive effect on the bidding price but it was not materialized in the real selling price, which could be explained by a lack of veracity in the information provided.

Finally, two studies have dealt with this matter for the residential sector of the US. Based on their results, Wall et al. (2013) argue that in Austin, Portland and the research triangle area of North Carolina, the energy certificate is only effective for the price of old homes, not for new ones. In turn, Kahn and Kok (2014) found a WTP of $9 \%$ of the selling price for certified homes in California ${ }^{12}$.

This same outcome for energy certificates in buildings has been replicated in other areas of household energy use. In particular, two papers have estimated a positive WTP for energy certificates for private vehicles. Galarraga et al. (2013) found that efficient cars (with an A or B certificate) are sold at a premium between $2.1 \%$ and $9 \%$ more than other cars in Spain. Alberini et al. (2014) used matching estimators and a regression discontinuity design to estimate the value of $A$ labels in Switzerland. Their results show that the price of an $A$ label ranges between $5 \%$ and $6-11 \%$ for each methodology.

Estimation of WTP from stated preferences for appliances has been quite widespread. Some examples are Sammer and Wüstenhagen (2006), for washing machines in Switzerland; Wallander (2008), who combines hedonic pricing with discrete choice models for EnergyStarcertified washing machines in the US; Shen and Saijo (2009), with a latent class approach to analyze the case of air conditioners and refrigerators with the China Energy Efficiency Lab in Shanghai; Ward et al. (2011), who do the same for refrigerators in the US; Galarraga et al. (2011), with the use of hedonic pricing to estimate the WTP for efficient dishwashers in Spain; and Newell and Siikamäki (2014), who do the same for EnergyStar water heaters in the US.

\footnotetext{
12 There have also been studies to determine the effect of energy certificates on appliances and vehicles. Recently, Houde (2014a) used a natural experiment (the change in the requirements for refrigerator certificates in the US) to estimate the treatment effect of certificates. With a structural model, he obtained three types of answers: those who value the EnergyStar label even more than the energy savings implied, those who only value the information about the energy use, and those who do not value any of these characteristics.
} 
Some studies about appliances have pointed out the need to tailor the information included on the label to the specific circumstances of consumers. For example, Davis and Metcalf (2014) evaluated the quality of the information provided by the mandatory labels for appliances used in the U.S. They wondered whether state-specific labels tailored to the state of residence of each participant would be efficient and thus they carried out an online choice experiment where participants had to choose to hypothetically purchase one of three air conditioners. The control group was shown an official energy label providing consumers with information on the expected annual energy cost according to national energy prices and use, while in the treatment group an alternative label was shown with information on expected annual energy costs based on state energy prices and uses. Their results show that state-specific labels lead to significantly better choices, although they also indicate that consumers do not fully understand the information displayed in the label.

The informational value of an energy certificate or label could also be substituted by an informal procedure. Allcott and Sweeney (2015) developed a natural experiment in collaboration with an appliance retailer, in which 20,000 customers who bought water heaters were offered two levels of information: some were told about the energy efficiency of the heaters, while others were not. Their results show that this information has a limited effect, although this may be owed to the fact that only explicitly interested customers received information. Another explanation, of course, would be the lower level of trust the customers may have placed on the sales agents (as compared to a well-established certificate).

Allcott and Taubinsky (2015) also run two randomized control trials to estimate the impact of information on the decision to buy compact fluorescent bulbs. The first is a choice experiment, through Internet, that estimates the effect of randomly providing information of the energy cost and lifetime of the product. The second provides information through a sales agent who randomly intercepts customers in a shopping mall and asks them to fill in a questionnaire. Results show that information was significant only in the first experiment.

Another way to offer information about the energy performance of a product is to express it in monetary terms. In the 1980s some experiments measured the effect of informing about the energy costs of appliances, with a survey on these studies showing mixed results (Kaenzig and Wüstenhagen, 2009). The recent introduction of energy certificates in the US and Europe has spurred renewed academic interest in this issue. Deutsch (2010) carried out an online field experiment in which he attempted to estimate the effect of providing information about the life cycle cost of washing machines sold by a German online website. In this experiment consumers were randomly assigned to two groups, one receiving the life cycle cost information and the other not receiving it. Results show that this information reduced the energy use of the washing machines sold by $0.8 \%$. 
And of course, monetary costs can be added to energy performance labels. Kallbekken et al. (2013) ran an experiment in Norway in which they provided information about energy costs through an experimental energy label (developed by the seller) showing the operational cost over the lifetime of dryers and refrigerators, which was additional to the information on the mandatory energy label. They also trained sales agents to inform customers about this matter. Just like Allcott and Sweeney (2015) did, they found no significant effect of this additional information in the case of refrigerators, but they did find a positive and significant one for dryers (although there was no effect for the energy label alone).

\subsection{Feedback}

Over the last decades information on the household use of energy (feedback) has represented an instrument to achieve energy savings. If consumers are aware of the way they use energy and its cost, they should be interested in reducing their energy consumption. Of course, this strategy could also backfire: if consumers find that they use or spend less than expected, they might even increase their consumption.

Feedback can also augment the effectiveness of other instruments by increasing the elasticity of demand. For example, Jessoe and Rapson (2014) observed in a field experiment that the effect of a price change was higher in households that received real-time information (through a smart meter) than it was in the control group.

Abrahamse et al. (2005) reviewed 38 studies carried out between 1977 and 2004 to assess the effectiveness of feedback programs (through meters in 13 experiments). Results showed that this information can sometimes produce energy savings and that its effectiveness increases as does the frequency in which the information is received. This review also included the results of three experiments providing information on a comparative basis: in two of them the differences were insignificant, while the third one did produce some energy savings in gas and electricity thanks to the exchange of information between groups of neighbors in the Netherlands (Staats et al., 2004).

Darby (2006) reviewed almost 30 studies in the US, Canada, Scandinavia, the Netherlands and the UK, and concluded that immediate feedback through a monitor or meter reduced energy use between 5 and 15\% (and between 0 and 10\% through bills). Fischer (2008) updated the review of Abrahamse et al. (2005) and Darby (2006) and added 24 more studies carried out between 1987 and 2006. Recently, research has also expanded to other channels and goods. For example, in a random field experiment in Denmark on 1,452 households, Gleerup et al. (2010) sent feedback (through email or cell phone texts) to some consumers, informing them that they had used an 
exceptionally high amount of electricity for a certain period. Informed consumers reduced their energy use by $3 \%$ on average ${ }^{13}$.

Since the most frequent channels used to convey this feedback have been smart meters and energy bills, we next now look at them in detail.

\subsubsection{Smart meters}

As aforementioned, the effectiveness of feedback increases as the frequency in which it is received increases (Ehrhardt-Martinez et al., 2010). Therefore, smart meters may increase the savings achieved ${ }^{14}$. These meters also allow for more rigorous experiments, as compared to the small-size, not-always-random studies carried out in the first years (which were typically based on voluntary pilot programs).

There are already some estimates about the effect of smart meters on energy savings. Faruqui, et al. (2010) concluded that the average reduction in energy use was $7 \%$, without accounting for the impact of time-dependent tariffs. Similarly, Gans et al. (2013) found that energy use in Ireland dropped between 11 and 17\% when smart meters replaced old meters in a natural experiment. Houde et al. (2013) collaborated with Google in an experiment in which over 1,500 Google employees participated voluntarily. Households were randomly assigned to the treatment group, which received a device that metered energy use every 10 minutes and made the information public on a webpage together with additional information. The experiment led to a $5.7 \%$ reduction of energy use, although reductions ceased to be significant after four weeks.

\subsubsection{Energy bills with comparative information}

Another way of giving feedback is through bills that provide information on household energy use and how it compares to others. This option has been considered since the 1980s (EhrhardtMartinez et al., 2010), but only recently has it been proposed as an effective feedback to alter behavior (Croson and Treich, 2014) and thus considered as another type of behavioral intervention or green nudge.

This type of information uses social pressure to attempt to nudge consumers into adopting more energy-efficient decisions (DellaVigna, 2009). The most studied case consists in including

\footnotetext{
${ }^{13}$ The authors remark that this value is not significant for all the model specifications, which could be due to the small size of the treatment groups.

${ }^{14}$ Smart meters are being rolled out differently in different regions, with some technical and data privacy problems. The 2012/27/UE Directive requires all member states to ensure that all customers have real-time meters. However, the cost effectiveness of meters for energy savings is not clear, as shown by Conchado and Linares (2012), who review the economic impacts of these programs.
} 
information about the energy use of similar homes on the energy bill, so that consumers with a higher consumption may be inclined to reduce their consumption ${ }^{15}$. In Europe, for instance, this information is regulated by the Directive 2012/27/EU, and must be included in the bill whenever possible. As compared to smart meters, bills offer a much more inexpensive way to provide feedback (and achieve energy savings).

A growing number of empirical studies have looked at this effect, and are summarized in Table 4 with their technical characteristics and results. The first review, carried out by Fischer (2008) for 12 empirical studies that used some type of comparative information, did not find impacts on energy use. Fischer argued that this might be explained by the increase in consumption of lowerthan-average households that cancels out the reduction in others. According to Schultz et al. (2007) this may be due to the lack of historical information on their own consumption (injunctive messages) and the potential rebound of this veil of ignorance (boomerang effect).

Table 4: Empirical Evidence from Studies of Comparative Energy Bills

\begin{tabular}{|c|c|c|}
\hline Study & Sample & Results \\
\hline Nola et al. (2008) & $\begin{array}{l}810 \text { households, } \\
\text { California }\end{array}$ & Consumption decreases \\
\hline \multirow[t]{2}{*}{ Schultz et al. ( 2007) } & \multirow[t]{2}{*}{$\begin{array}{l}290 \text { households, } \\
\text { California }\end{array}$} & $\begin{array}{l}-1.22 \mathrm{kWh} / \text { day for households above the } \\
\text { average using descriptive information }\end{array}$ \\
\hline & & $\begin{array}{l}-1.72 \mathrm{kWh} / \text { day for households above the } \\
\text { average using descriptive and injunctive } \\
\text { information }\end{array}$ \\
\hline Allcott (2011) & $\begin{array}{l}600,000 \text { households, } \\
\text { U.S. }\end{array}$ & $-2 \%$ average, significant heterogeneity \\
\hline \multirow[t]{2}{*}{ Ayres et al. (2012) } & \multirow{2}{*}{$\begin{array}{l}84,000 \text { households, } \\
\text { U.S. }\end{array}$} & $-1.2 \%$ gas \\
\hline & & $-2.1 \%$ electricity \\
\hline \multirow[t]{2}{*}{ Costa and Kahn (2013) } & \multirow{2}{*}{$\begin{array}{l}\text { Treatment group of } \\
\text { approximately } 35,000 \\
\text { households. } \\
\text { A control group of } \\
\text { roughly } 49,000 \\
\text { households that have } \\
\text { never received a Home } \\
\text { Electricity Report in U.S. }\end{array}$} & $\begin{array}{l}-3.1 \% \text { consumption for: registered liberal } \\
\text { who pays for electricity from renewable } \\
\text { sources, who donates to environmental } \\
\text { groups, and who lives in a liberal } \\
\text { neighborhood reduces consumption }\end{array}$ \\
\hline & & $\begin{array}{l}+0.7 \% \text { for: registered as conservative do not } \\
\text { pay for electricity from renewable sources, } \\
\text { do not donate to environmental groups, and } \\
\text { live in the bottom quartile liberal } \\
\text { neighborhood }\end{array}$ \\
\hline Allcott and Rogers (2014) & $\begin{array}{l}\text { The initial experiment } \\
\text { population was } 234,000 \\
\text { households in U.S. }\end{array}$ & $\begin{array}{l}\text { Consumption decreases immediately but } \\
\text { decays after less than two weeks. }\end{array}$ \\
\hline
\end{tabular}

Source: The authors.

15 Schultz et al. (2007) warn that, in order to avoid a negative effect in households with lower-than-average consumption, it is also recommendable to include information on the historic consumption of the household. 
Nola et al. (2008) ran a first experiment in California in which they found that, although households do not consider this comparative information relevant for making decisions, those that received this information in a second experiment reduced their energy use. More recently, the U.S. utility OPower, carried out a large-scale random experiment, The Home Energy Report ${ }^{16}$. Its goal was to assess the effect of including comparative information about the energy use of a similar home in the gas or electricity bill and it also incorporated historical information about the own consumption of the home (see note 15). Several studies have been produced from this experiment. Allcott (2011) found that, for a sample of 600,000 households distributed across the US, this information reduced energy use by $2 \%$ on average. Ayres et al. (2012) used two subsamples, one for electricity-only use and the other for gas and electricity, showing a reduction in energy use of between 1.2 and $2.1 \%$, although the effects were limited in time (7 months for gas and 12 months for electricity). The issue of persistency of effects after the end of the intervention was specifically addressed by Allcott and Rogers (2014) with the use of a longer sample of the OPower experiment. Their results suggested that the effect decays two weeks after the intervention ends, although the persistency is higher if the intervention is longer. This could be explained by a gradual change in both the habits and the technology of consumers.

Finally, and following Costa and Kahn (2013), it is worth noting that there is a large heterogeneity in the residential sector. Therefore, savings can vary substantially depending on the typology of the households and their political or environmental orientation.

\subsection{Energy audits}

Energy audits are another way to convey information about energy efficiency to consumers. With personalized audits, consumers may be aware of the potential for reducing energy use in their homes. Therefore, their major advantage is that they offer tailored information. However, the cost is high, and it often requires support from public administrations or energy companies. In Europe, the 2012/27/EU Directive requires member states to promote and facilitate energy audits among final consumers, as long as they are cost-efficient, carried out by certified agents, and supervised by national authorities.

Researchers agree that the major difficulty in assessing this informational instrument is the selfselection bias due to the voluntary nature of audits. The above-mentioned review of Abrahamse et al. (2005) compiles the results of five studies of energy audits, carried out before 2004. These results vary: while some of them find a significant reduction in electricity and gas use, others do not find any evidence of this reduction. Once again, the disparity of results may be explained by the heterogeneity of the samples. Frondel and Vance (2012) reach a similar conclusion, finding

${ }^{16}$ Accessible on http://opower.com/. 
very diverse outcomes for energy audits in Germany, depending on the households studied. They even encounter cases in which the information provided through the audit renders negative effects for energy efficiency investments. These problems led Palmer et al. (2011), in a survey of almost 500 energy service companies, to inquire on the difficulties encountered by this instrument. The major problems they pointed out were difficulties in understanding the results of the audits, their direct cost, and the cost of the recommended improvements.

\section{Conclusions and directions for future research}

Conventional energy efficiency policies such as building codes or standards, or pricing systems, have not been effective in the residential sector, which is actually increasing its energy use (and carbon emissions) in most countries. Part of the reason for this may lie in the complexity of this sector, with its many dualities (renters vs. owners, commercial vs. residential, etc.) that complicate institutional arrangements and the use of traditional instruments. However, another very powerful explanation is that the assumption of perfect information and rational decisionmaking is less valid in this sector than it is in others. Indeed, many researchers have identified the significant contribution of information and behavioral problems to the energy efficiency gap in this sector.

Therefore, it makes sense to explore other tools (which we might term second generation instruments) that directly address these problems. Implementing these alternative instruments may be substantially less costly than implementing the traditional ones and thus could bring about a simultaneous improvement in the cost-efficiency of public policies. A relevant question then is how effective are these information-based instruments. In this paper we have reviewed the evidence on the effectiveness of energy certificates and labels, feedback programs, and energy audits. Our results reveal that there are clear advantages for some yet not for others.

Energy certificates and labels show great potential. Most of the studies carried out indicate a positive WTP by consumers for them (up to $20 \%$ in some cases), which is consistent with the reductions observed in energy use. This result has not only been obtained for buildings but also for appliances and vehicles. Yet some of this information must be taken with care as, first, results are less positive for residential buildings than they are for commercial buildings. This signals lower value of the information in the former, which in turn may be related to a less-rational decision-making process. Clearly, there is a need to address more factors in play in the residential sector.

Second, there are cases in which WTP is non-significant or even negative. This may be owed to different reasons such as the way certificates are designed. The studies reviewed show that the way the information is framed determines the results: it is more powerful to show energy savings 
or economic losses than it is to present potential benefits. Government backing is also much valued, giving credibility and stability to the certificates. These features probably explain why informal or private information procedures show a limited effect, a much lower one than certificates do. Finally, consumers may be deterred by higher maintenance costs, or potential rebound effects of more efficient equipment even if the certificates show energy savings.

Feedback programs are shown to be less effective than certificates or labels. Here the energy savings achieved an average 2-3\%. These programs can be very inexpensive, though, as is the case when the feedback is given through energy bills, and they can also use social pressure (through comparative information) as a driver for energy efficiency. However, research has shown that the frequency with which the feedback is given matters a great deal, and energy bills are not all that frequent. Here smart meters may play a much bigger part, in fact frequent feedback information provided by these devices has shown to achieve reductions of up to $15 \%$ in energy use. Evidently they are more expensive but we will return to this matter later. Two more important problems must also be noted. The first is the fact that feedback might result in increases in energy use in the case of consumers that are already efficient. Some authors propose that historic information be included to control for this. The second and most relevant problem is the persistency of the savings, which has been shown to be rather low. Habit-formation and technological changes seem to require longer and more frequent interventions.

Finally, many governments promote a very popular instrument, energy audits. Although energy audits are personalized (and therefore address heterogeneity) and they have many politicaleconomy advantages, the results of the studies reviewed have rendered mixed (not clearly positive) effects. Combined with its high cost and its complex implementation, this makes audits probably the least interesting of all the instruments reviewed.

Although informational instruments seem to be very promising, they also present clear shortcomings. Despite clearly adding very relevant channels to the ones covered by conventional instruments, some factors explaining the energy efficiency gap in the residential sector still need to be addressed (and researched). One is the large transaction cost for households when considering investing in energy efficiency. Even when investments are completely funded by the government there may be significant transaction costs which could discourage consumers from investing even if they have been provided with the information to reduce energy consumption (Fowlie et al., 2015). Reducing transaction costs for households is a difficult issue, similar to the one presented by bounded rationality (or limited attention) inherent to many of these decisions. Innovative approaches are clearly required here. Another very relevant problem requiring novel institutional arrangements is the principal-agent problem, pervasive in this sector, which is neither addressed by conventional nor informational instruments.

One way to move forward may be to combine instruments and promote new designs for conventional instruments. The Carbon Reduction Commitment (CRC) of the UK, a complement to 
the EU Emissions Trading System for the commercial sector that addresses low-energy-intensive activities in high demand is a good example. Another interesting instrument is the one recently proposed by Rodríguez et al. (2012) and Gago et al. (2013), a new tax on energy inefficiency. This tax would be based on the energy certificate system, and would employ a fixed charge per area unit, depending on the type of certificate.

Of course, more research is needed to study the applicability and effectiveness of these new designs. New information and communication technologies also open up new possibilities to design instruments, even though this may also involve high costs. This takes us to our final point, which is the need to study all these instruments not only from the point of view of effectiveness but also from the perspective of welfare. Little research is available on this, but some authors already indicate possible situations in which welfare effect is not clear. Mahenc (2007), for example, studies the possible overpricing of green products, whereas Houde (2014b) and Cohen et al. (2014) argue that manufacturers may respond to energy certificates and standards with price discrimination and other strategies. The cost-benefit analysis for the deployment of smart meters, for instance, is not clear either (see e.g. Conchado and Linares, 2010).

In this article, as in many review papers, we end up with more questions than answers. We signal the many advantages of some well-designed second-generation instruments, such as energy certificates or feedback programs, and the limitations of energy audits. However we also observe that much more work is required to explore the potential of alternative instruments and assess their cost-efficiency. This is undoubtedly an area full of potential for energy economics researchers.

\section{Acknowledgments}

The authors are grateful to the Spanish Ministry of Science and Innovation project ECO201341183-P. Yet the paper only reflects the views of the authors, who are responsible for any error or omission that may remain. 


\section{References}

Abrahamse, W., Steg, L., Vlek, C., Rothengatter, T. (2005). A review of intervention studies aimed at household energy conservation. Journal of Environmental Psychology, 25, 273-291.

Achtnicht, M. (2011). Do environmental benefits matter? Evidence from a choice experiment among house owners in Germany. Ecological Economics, 70, 2191-2200.

Alberini, A., Bareit, M., Filippini, M. (2014). Does the Swiss car market reward fuel efficient cars? Evidence from hedonic pricing regressions, matching and a regression discontinuity. CER-ETHCenter of Economic Research at ETH Zurich. Working paper 14/190.

Alberini, A., Banfi, S., Ramseier, C. (2013). Energy efficiency investments in the home: Swiss homeowners and expectations about future energy prices. Energy Journal, 34(1), 49-86.

Allcott, H., Taubinsky, D. (2015). Evaluating behaviorally-motivated policies: Experimental evidence from the lightbulb market. American Economic Review, forthcoming.

Allcott, H., Sweeney, R. (2015). Can retailers inform consumers about energy costs? Evidence from a field experiment. E2e. Working paper 008.

Allcott, H., Rogers, T. (2014). The short-run and long-run effects of behavioral interventions: Experimental evidence from energy conservation. American Economic Review, 104(10), 30033037.

Allcott, H., Greenstone, M. (2012). Is there an energy efficiency gap? Journal of Economic Perspectives, 26(1), 3-28.

Allcott, H. (2011). Social norms and energy conservation. Journal of Public Economics, 95(9-10), 1082-1095.

Allcott, H., Mullainathan, S. (2010). Behavior and energy policy. Science, 327, 1204-1205.

Aroonruengsawat, A., Auffhammer, M., Sanstad, A.(2012). The impacts of state level building codes on residential electricity consumption. Energy Journal, 33(1), 31-52.

Ayres, I., Raseman, S., Shih, A. (2012). Evidence from two large field experiments that peer comparison feedback can reduce residential energy usage. Journal of Law, Economics, and Organization, 29(4), 1-31.

Banerjee, A., Solomon, B. (2003). Eco-labeling for energy efficiency and sustainability: a metaevaluation of US programs. Energy Policy, 31, 109-123.

Banfi, S., Farsi, M., Filippini, M., Jakob, M. (2008). Willingness to pay for energy-saving measures in residential buildings. Energy Economics, 30, 503-516.

Bloom, B., Nobe, M.C., Nobe, M.D. (2011). Valuing green home designs: A study of ENERGY STAR homes. Journal of Sustainable Real Estate, 3(1), 109-126.

Blumstein, C., Kreig, B., Schipper, L., York, C. (2004). Overcoming social and institutional barriers to energy efficiency. Energy, 5, 1921-1933.

Brechling, V., Smith, S. (1994). Household energy efficiency in the UK. Fiscal Studies 15, 44-56.

Brounen, D., Kok, N., Quigley, J. (2013). Energy literacy, awareness, and conservation behavior of residential households. Energy Economics, 38, 42-50.

Brounen, D., Kok, N. (2011). On the economis of energy labels in the housing market. Journal of Environmental Economics and Management 62, 166-179. 
Brown, Z., Johnstone, N., Hascic, I., Vong, L., Barascud, F. (2013). Testing the effect of defaults on the thermostat settings of OECD employees. Energy Economics, 39, 128-134.

Bull, J. (2012). Loads of green washing - can behavioral economics increase willingness-to-pay for efficient washing machines in the UK? Energy Policy, 50, 242-252.

Cajias, M., Piazolo, D. (2013). Green performs better: Energy efficiency and financial return on buildings. Journal of Corporate Real Estate, 15(1), 53-72.

Chau, C., Tse, M., Chung, K. (2010). A choice experiment to estimate the effect of green experience on preferences and willingness-to-pay for green building attributes. Building and Environment, 45, 2553-2561.

Chegut, A., Eichholtz, P., Kok, N. (2013). Supply, demand and the value of green buildings. Urban studies, May 16, 1-22.

Clinch, J., Healy, J. (2000). Domestic energy efficiency in Ireland: correcting market failure. Energy Policy, 28, 1-8.

Cohen, F., Glachant, M., Söderberg, M. (2014). The impact of energy prices on energy efficiency: Evidence from the UK refrigerator market. Presented at the $6^{\text {th }}$ Atlantic Workshop on Energy and Environmental Economics, A Toxa, Spain.

Conchado, A., Linares, P. (2012). The economic impact of demand-response programs on power systems. A survey of the state of the art. In Sorokin, A., Rebennack, S., Pardalos, P.M., lliadis, N.A., Pereira, M.V.F. (eds.). Handbook of networks in power systems. Springer, Berlin.

Costa, D., Kahn, M. (2013). Energy conservation 'nudges' and environmentalist ideology: Evidence from a randomized residential electricity field experiment. Journal of the European Economic Association, 11(3), 680-702.

Costa, D., Kahn, M. (2010a). Why has California's residential electricity consumption been so flat since the 1980? National Bureau of Economic Research, NBER. Working Paper 1597.

Croson, R., Treich, N. (2014). Behavioral environmental economics: Promises and challenges. Environmental and Resource Economics, 58, 335-351.

Das, P., Tidwell, A., Ziobrowski, A. (2011). Dinamics of green rentals over market cycles: Evidence from commercial office properties in San Francisco and Washington DC. Journal of Sustainable Real Estate, 3(1), 2-22.

Darby, S. (2006). The effectiveness of feedback on energy consumption. A review for DEFRA of the literature on metering, billing and direct displays. Environmental Change Institute, University of Oxford.

Davis, L.W., Metcalf, G.E. (2014). Does better information lead to better choices? Evidence from energy-efficiency labels. National Bureau of Economic Research, NBER. Working paper 20720.

Davis, L. (2012). Evaluationg the slow adoption of energy efficient invesetment: Are renters less likely to have energy efficient appliances? In D. Fullerton, C. Wolfram (eds), The design and Implementation of U.S. Climate Policy. University of Chicago Press, Chicago.

DellaVigna, S. (2009). Psychology and economics: Evidence from the field. Journal of Economic Literature, 47(2), 315-372.

Deng, Y., Li, Z., Quigley, J. (2012). Economic returns to energy-efficient investments in the housing market: Evidence from Singapore. Journal of Regional Science and Urban Economics, 42(3), 506-515. 
Deutsch, M. (2010). Life cycle cost disclosure consumer behavior, and business implications. Journal of Industrial Ecology, 14(1), 103-120.

Di Maria, C. F., Lazarova, E. (2008). Shedding light on the light bulb puzzle: Attitudes and perception. Scottish Journal of Political Economy, 57, 48-67.

Directive 2012/27/EU, of the European Parliament and of the Council of the 25 October 2012 on energy efficiency.

Directive 1999/94/CE, of the European Parliament and of the Council of 13 December 1999 relating to the availability of consumer informationon fuel economy and $\mathrm{CO}_{2}$ emissions in respect of the marketing of new passenger cars.

Directive 1992/75/CEE, of 22 September 1992 on the indication by labelling and standard product information of the consumption of energy and other resources by household appliances.

Dyner, I., Franco, C. (2004). Consumers' bounded rationality: The case of competitive energy markets. Systems Research and Behavioral Science, 21, 373-389.

Ehrhardt-Martinez, K., Donnelly, K., 'Skip' Laitner, J. (2010). Advanced metering initiatives and residential feedback programs: A meta-review for household electricity-saving opportunities. Washington. American Council for an Energy-Efficient Economy, Report E105.

Eichholtz, P., Kok, N., Quigley, J. (2013). The economics of green building. Review of Economics and Statistics, 95(1), 50-63.

Eichholtz, P., Kok, N., Quigley, J. (2010). Doing well by doing good: Green office buildings. American Economic Review, 100(5), 2494-2511.

European Commission. (2013). Report from the Commission to the European Parliament and the Council. Financial support for energy efficiency in buildings. COM(2013)225 final. Brussels.

European Commission. (2011). COM (2011) 109 final. Communication from the Commission to the European Parliament, the Council, the European Economic and Social Committee and the Committee of the Regions. Energy Efficiency Plan 2011. Brussels.

European Parliament. (2014). Report from the European Parliament on a 2030 framework for climate and energy policies (2013/2135(INI)). Committee on the Environment, Public Health and Food Safety; Committee on Industry, Research and Energy. Strassbourg.

Faruqui, A., Sergici, S., Sharif, A. (2010). The impact of informational feedback on energy consumption. A survey of the experimental evidence. Energy, 35, 1598-1608.

Fischer, C. (2008). Feedback on household electricity consumption: a tool for saving energy? Energy Efficiency, 1, 79-104.

Fowlie, M., Greenstone, M., and Wolfram, C. (2015). Are the non-monetary costs of energy efficiency investments large? Understanding low take-up of a free energy efficiency program. E2e Working Paper 016.

Frondel, M., Vance, C. (2012). Heterogeneity in the effect of home energy audits. theory and evidence. Environmental and Resource Economics, 55, 407-418.

Fuerst, F., McAllister, P. (2011a). Green Noise or Green Value? measuring the effects of environmental certification on office values. Real Estate Economics, 39, 45-69.

Fuerst, F., McAllister, P. (2011b). The impact of energy performance certificates on the rental and capital values of commercial property assets. Energy Policy, 39, 6608-6614. 
Fuerst, F., McAllister, P. (2011c). Eco-labeling in commercial office markets: Do LEED and Energy Star offices obtain multiple premiums? Ecological Economics, 70(6), 1220-1230.

Gago, A., Haneman, M., Labandeira, X., Ramos, A. (2013). Climate change, buildings and energy prices. In Fouquet, R. (ed.), Handbook on energy and climate change. Edward Elgar, Chetelham.

Galarraga, I., Ramos, A., Lucas, J., Labandeira, X. (2014). The price of energy efficiency in the spanish car market. Transport Policy, 36, 272-282.

Galarraga, I., González-Eguino, M., Markandya, A. (2011). Willingness to pay and price elasticities of demand for energy-efficient appliances: Combining the hedonic approach and demand systems. Energy Economics, 33, S66-S74.

Gans, W., Alberini, A., Longo, A. (2013). Smart meter devices and the effect of feedback on residential electricity consumption: Evidence from a natural experiment in Northern Ireland. Energy Economics, 36, 729-743.

Gillingham, K., Palmer, K. (2013). Bridging the energy efficiency gap. policy insights from economic theory and empirical evidence. Review of Environmental Economics and Policy, 8(1), 18-38.

Gillingham, K., Harding, M., Rapson, D. (2012). Split incentives in residential energy consumption. Energy Journal 33(2), 37-62.

Gillingham, K., Newell, R., Palmer, K. (2009). Energy efficiency and policy. Annual Review of Resource Economics 1(1), 597-620.

Gillingham, K., Newell, R., Palmer, K. (2006). Energy efficiency policies: a retrospective examination. Annual Review of Environmental Resources, 31, 161-192.

Gleerup, M., Larsen, A., Leth-Petersen, S., Togeby, M. (2010). The effect of feedback by text message (SMS) and email on household electricity consumption: Experimental evidence. Energy Journal, 31(3), 113-132.

Grösche, P., Vance, C. (2009). Willingness to pay for energy conservation and free-ridership on subsidization: Evidence from Germany. Energy Journal, 30, 135-154.

Högberg, L. (2013). The impact of energy performance on single-family home selling prices in Sweden. Journal of European Real Estate Research, 6(3), 242-261.

Houde, S. (2014a). How consumers respond to environmental certification and the value of energy information. National Bureau of Economic Research, NBER. Working paper 20019.

Houde, S. (2014b). Bunching with the stars: How firms respond to environmental certification. University of Maryland. Working paper.

Houde, S., Todd, A., Sudarshan, A., Flora, J., Armel, K. (2013). Real-time feedback and electricity consumption: A Field experiment assessing the potential for savings and persistence. Energy Jounal, 34(1), 87-102.

Hyland, M., Lyons, R.C., Lyons, S. (2013). The value of domestic building energy efficiency. Evidence from Ireland. Energy Economics, 40, 943-952.

IEA (2013). Transition to sustainable buildings. Strategies and opportunities to 2050. International Energy Agency, Paris.

IEA (2010). Energy performance certification of buildings. A policy tool to improve energy efficiency. Policy Pathway Series. International Energy Agency, Paris. 
IEA (2007). Mind the gap: quantifying principal-agent problems in energy efficiency. In support of the G8 Plan Action. International Energy Agency, Paris.

Iwaro, J., Mwasha, A. (2010). A review of building energy regulation and policy for energy conservation in developing countries. Energy Policy, 38, 7744-7755.

Jacobsen, G.D., Kotchen, M.J. (2013). Are building codes effective at saving energy? Evidence from residential billing data in Florida. Review of Economics and Statitistics, 95(1), 34-49.

Jaffe, A., Newell, R., Stavins, R. (2004). Economics of energy efficiency. Encyclopedia of Energy 2, 79-90.

Jaffe, A., Stavins, R. (1994). The energy-efficiency gap. What does it mean? Energy Policy 22, 804-810.

Jessoe, K., Rapson, D. (2014). Knowledge is (less) power: Experimental evidence from residential energy use. American Economic Review, 104(4), 1417-1438.

Kaenzig, J., Wüstenhagen, R. (2009). The effect of life cycle cost information on consumer investment decisions regarding eco-innovation. Journal of Industrial Ecology, 14(1), 121-136.

Kahn, M., Kok, N. (2014). The capitalization of green label in the California housing market. Regional Science and Urban Economics, 47, 25-34.

Kahn, M., Vaughn, R. (2009). Green market geography: The spatial clustering of hybrid vehicles and LEED registered buildings. The B.E. Journal of Economic Analysis and Policy, 9(2), 19351682.

Kahneman, D. (2011). Thinking, fast and slow. Farrar, New York.

Kahneman, D., Tversky, A. (1979). Prospect theory: An analysis of decision under risk. Econometrica, 47(2), 263-292.

Kallbekken, S., Saelen, H., Hermansen, E. (2013). Bridging the energy efficiency gap: A field experiment on lifetime energy costs and household appliances. Journal of Consumer Policy, 36, $1-16$.

Kok, N., Jennen, M. (2012). The impact of energy labels and accessibility on office rents. Energy Policy, 46, 489-497.

Kotchen, M., Moore, M. (2007). Private provision of environmental public goods: Household participation in green-electricity programs. Journal of Environmental Economics and Management, 53, 1-16.

Kwak, S., Yoo, S., Kwak, S. (2010). Valuing energy-saving measures in residential buildings: A choice experiment study. Energy Policy, 38, 673-677.

Lange, I., Moro, M., Traynor, L. (2014). Geen hypocrisy? environmental attitudes and residential space hating expenditure. Ecological Economics, 107, 76-83.

Levinson, A. (2014). How much energy do building energy codes really save? Evidence from California. National Bureau of Economic Research, NBER. Working Paper 20797.

Levinson, A., Niemann, S. (2004). Energy use by apartment tenants when landlords pay for utilities. Resources and Energy Economics 26, 51-75.

Linares, P., Labandeira, X. (2010). Energy efficiency. Economics and policy. Journal of Economic Surveys, 24, 573-592. 
Loomes, G., and Sugden, R. 1982. Regret theory: An alternative theory of rational choice under uncertainty. The Economic Journal, 92(368): 805-824.

Mahenc, P. (2007). Are Green products over-priced? Environmental and Resource Economics, 38, 461-473.

Markandya, A., Labandeira, X., Ramos, A. (2015). Policy instruments to foster energy efficiency. In Ansuategi, A., Delgado, J., Galarraga, I. (eds.) Green energy and efficiency. An economic perspective. Springer, Berlin.

Maruejols, L., Young, D. (2011). Split incentives and energy efficiency in Canadian multi-family dwellings. Energy Policy, 39, 3655-3668.

Mlecnik, E., Visscher, H., Van Hal, A. (2010). Barriers and opportunities for labels for highly energy-efficient houses. Energy Policy, 38, 4592-4603.

Mourato, S., Saynor, B., Hart, D. (2004). Greening London's black cabs: a study of driver's preferences for fuel cell taxis. Energy Policy, 32, 685-695.

Muehlegger, K., Gallagher, E. (2011). Giving green to get green? Incentives and consumer adoption of hybrid vehicle technology. Journal of Environmental Economics and Management, 61,1-15.

Mullainathan, S., Thaler, R. (2000). Behavioral economics. MIT Department of Economics. Working paper 00-27.

Nair, G., Gustavsson, L., Mahapatra, K. (2010a). Owners perception on the adoption of building envelope energy efficiency measures in Swedish detached houses. Applied Energy, 87, 24112419.

Nair, G., Gustavsoon, L., Mahapatra, K. (2010b). Factors influencing energy efficiency investments in existing Swedish residential buildings. Energy Policy, 38, 2956-2963.

Newell, R., Siikamäki, J. (2014). Nudging energy efficiency behavior: The role of information labels.Journal of the Association of Environmental and Resource Economists, 1(4), 555-598..

Newsham, G.R., Mancini, S., Birt, B.J. (2009). Do LEEd-certified buildings save energy? Yes, but... Energy and Buildings, 41, 897-905.

Nola, J., Schultz, P., Cialdini, R., Goldstein, N. G. (2008). Normative social influence is underdetected. Personality and Social Psychology Bulletin, 34, 913-923.

OECD (2003). Environmentally Sustainable Buildings: Challenges and Policies. OECD, Paris.

Palmer, K., Walls, M., Gordon, H., Gerarden, T. (2011). Assessing the energy efficiency information gap: Results from a survey of home energy audits. Resources for the Future. Working paper DP 11-42.

Ramos, A., Labandeira, X., Löschel, A. (2015). Pro-environmental households and energy efficiency in Spain. Economics for Energy, Working paper 01/2015.

Reichardt, A., Fuerst, F., Rottke, N.B., Zietz, J. (2012). Sustainable building certification and the rent premium: A Panel data approach. Journal of Real Estate Research, 34(1), 99-126.

Rodríguez, A., Vinagre, J., Wilby, M. (2012). Dedicated tax/subsidy scheme for reducing emissions by promoting innovation in buildings: The EcoTax. Energy Policy, 51, 417-424.

Rosen, S. (1974). Hedonic prices and implicit markets: Product differentiation in pure competition. Journal of Political Economy, 82, 34-55. 
Ryan, L., Moarif, S., Levina, E., Baron, R. (2011). Energy efficiency policy and carbon pricing. Information Paper. IEA, Paris.

Sammer, K., Wüstenhagen, R. (2006). The influence of eco-labelling on consumer behavior. Results of a discrete choice analysis for washing machines. Business Strategy and the Environment, 15, 185-199.

Schleich, J., Gruber, E. (2008). Beyond case studies: Barriers to energy efficiency in commerce and the services sector. Energy Economics, 30, 449-464.

Schultz, P., Nolan, J., Cialdini, R., Goldstein, N., Griskevicius, V. (2007). The constructive, destructive, and reconstructive power of social norms. Psychological Science, 18(5), 429-434.

Scott, S. (1997). Household energy efficiency in Ireland: A replication study of ownership of energy saving terms. Energy Economics, 19, 187-208.

Shen, J., Saijo, T. (2009). Does an energy eficiency label alter consumers' purchasing decisions? A latent class approach based on a stated choice experiment in Shanghai. Journal of Environmental Management, 90, 3561-3573.

Shogren, J., Taylor, L. (2008). On behavioral economics. Review of Environmental Economics and Policy 2(1), 26-44.

Simon, H.A. (1955). A behavioral model of rational choice. Quarterly Journal of Economics 69, 99-118.

Staats, H., Harland, P., Wilke, H. (2004). Effecting durable change. A team approach to improve environmental behavior in the houshold. Environment and Behavior, 36(3), 341-367.

Stavins, R., Schatzki, T., Borck, J. (2013). An economic perspective on building labeling policies. Analysis Group, Economic Financial and Strategy Consultants. Boston.

Stern, P., Aronson, E., Darley, J., Kempton, W., Hill, D., Hirst, E. (1987). Answering behavioral questions about energy efficiency in buildings. Energy, 12(5), 339-353.

Thaler, R.H., and Sunstein, C.R. (2008). Nudge: Improving decisions about health, wealth, and happiness. Yale University Press, New Haven.

Tietenberg, T. (2009). Reflections on energy efficiency policy: Pipe dream or pipeline to the future? Review of Environmental Economics and Policy, 3(2), 304-320.

Ürge-Vorsatz, D., Novikova, A. (2008). Potentials and costs of carbon dioxide mitigation in the world's buildings. Energy Policy, 36, 642-661.

Wall, M., Palmer, K., Gerarden, T. (2013). Is energy efficiency capitalized into home prices? Resources for the Future. Working paper DP 13-18.

Wallander, S. (2008). Price impacts of the energy star label. The power of redundant information. Yale Environmental Economics Seminar Paper.

Ward, D., Clark, C., Jensen, K., Yen, S., Russell, C. (2011). Factors influencing willingness-topay for the ENERGY STAR label. Energy Policy, 39, 1450-1458.

Wiley, J., Benefield, J., Johnson, K. (2010). Green design and the market for commercial office space. Journal of Real Estate Finance and Economics, 41, 228-243.

Yoshida, J., Sugiura, A. (2011). Which "greenness" is valued? Evidence from green condominiums in Tokyo. MPRA paper 23124. 
Zheng, S., Wu, J., Kahn, M., Deng, Y. (2012). The nascent market for "green" real estate in Beijing. European Economic Review, 56, 974-984. 